\title{
Investigation of potential toxic effects of construction waste runoff collected from illegal dumping site using brine shrimp and zebrafish models
}

\begin{abstract}
Urbanization results in the increment of construction waste, which eventually contaminate the surrounding environment and affects the ecosystem. This study aimed to investigate the potential toxic effects of construction waste runoff collected from an illegal construction waste dumping site, Kampung Sungai Pelong, Malaysia by using brine shrimp (Artemia sp.) and zebrafish (Danio rerio). The runoff sample collected in January 2018 proceeded with the physicochemical test, heavy metal analysis and bio-toxicity study. Several physicochemical properties (BOD, TSS, NH3-N and NO3-) and heavy metal content $(\mathrm{Cu}>\mathrm{Cd}>\mathrm{Ni}>\mathrm{As}>\mathrm{Pb}>\mathrm{Cr}>\mathrm{Hg})$ of runoff had values significantly exceeding the respective Class IIA Malaysia National Water Quality Standards. No mortality and abnormal swimming behaviour were observed for brine shrimp acute assay, but severely damage appendages and pigmentation were evident. In the zebrafish sub-acute assay, no constant trend of mortality was observed, but abnormal swimming pattern and alterations in gill tissue (cell vacuolation and clubbed tips). The results signify the potential eco-toxicity caused by construction waste runoff and urge the need for long-term toxicity study and strict legislative actions by the local authority.
\end{abstract}

Keyword : Lethal effect; Surface runoff; Kampung Sungai Pelong; Demolition waste 